\title{
Petrochemistry of Volcanic Rocks in Relation to The Formation of Island Ares (*)
}

\author{
G. S. GorshKov (**) \\ Ricevuto il 7 dicembre 1960.
}

As it is known the volcanic rocks of island arcs have a pronounced calc-alkali character. They vary in the content from olivine or nonolivine basalts to quartz-bearing dacites and zhyolites. The most widespread group of rocks in the series are pyroxene-andesite and transitional varieties - andesite-basalt and dacite. Characteristic feature of this series is a very basic plagioclase even in acid varieties and as well as frequent presence of quartz. Among the darc coloured minerals there occur rhombic pyroxenes or poor in lime clinopyroxenes of pigeonite type, often clinopypoxene is represented by diopside augite (especially in more basic rocks). In acid rocks pyroxene is replaced by hornblende and in exeptionally acid members of this series biotite and orthoclase appear.

Closer to the continents from island arc a gradual growth of alcalinity of rocks is encountered. The changing of petrochemical characteristics is noticable already at the distance of $10-12 \mathrm{~km}$ across the pitch of the arc. Numerous examples of such an alteration occur in Kamchatka, Kurile Islands and in Japan. At the distance of scores of kilometers it is possible to observe the changes in the mineral composition of rocks.

At first these changes are observed in acid rocks only, the plagioclase becoming more acid; almost always biotite or orthoclase occur and sometimes both minerals occur together. Pyroxene is more often represented by diopside augite. Still closer to the continent orthoclase acquires greater importance, it appears even in andesites often forming margins around plagioclase. Rhombic pyroxene disappear giving way to hornblende and diopside augite. As to the chemical composition the role of potassium in relation to sodium becomes greater.

(*) Paper read at the Helsinky Assembly of the I.U.G.G. 1960.

(**) Laboratory of Vulcanology, Acad. of Sci. of the U.S.S.R. Moscow. 
Intercontinental volcanoes now issue purely alkalic lavas distinctly having pure alkalic composition characteristic both for acid and basic kinds of rocks (from limburgite basanites and trachybasalts to trachytes and phonolites). The mineral composition reflects this phenomena by the presence potassium-sodium feldspars, aegirine-augites, titano-augites, alkaline ampliboles and at last feldspathoides-leucite and nepheline. Potassium rocks often dominate.

In the direction from island arcs to the ocean a sharp substitution of calc-alkalic rocks by alkaline lavas characteristic for all oceanic islands (a series of rocks from picrite-basalts and nepheline basalts to trachytes) takes place. Olivine basalts with more acid plagioclase (than in basalts of island ares) dominate here with pigeonite in the main mass. In andesites of this series plagioclase is represented by andesine and oligloclase, then alkalic amphiboles appear and in the main mass biotite occurs.

It is not always easy to distinguish the rocks of different series (oceanic, island ares and continental) by their mineral composition but by their petrochemical features they can be distinguished guite readily. Petrochemical calculations and comparison are possible to perform by different methods (Harken, NigGLI, C.I.P.W., etc.) but all these are rather complicated and permit to compare visually not more than two rock series simultaneously. I made use of A. N. Zavaritsky's method which permits to draw a quantity of analyses on a diagram and compare any number of rocks series.

The petrochemical method by Zavaritsky allows to express on a plane diagram for each rock at the same time: the ratio between salic and femic constituents, the ratio between alkaline and calcareous alumosilicates, the nature of alkaline alumosilicates (ratio $\mathrm{Na}$ to $\mathrm{K}$ ) and the nature of the femic constituents (ratio $\mathrm{Fe}, \mathrm{Ca}, \mathrm{Mg}$ and $\mathrm{Al}$ ). This method is considered in details in a book "The Introduction into the Petrochemistry of Inneous Rocks" (in Russian). As far as the author is informed it is translated only into German of all the Western-European languages. One can found all details in "Einfürung in die Petrochemie der Eruptivgesteine" by $\Lambda$. N. Zawaritzki, Berlin, AkademieVerlag, 1954.

On the graph (Fig. 1) variation curves for the series of oceanic, continental and island arcs lavas are drawn according to $\mathrm{A}$. N. Zavaritsky. To make the graph more simple figurative points of rocks and their vectors are omitted.

Upon considering the graph it becomes obvious that as a matter of fact there are two classes of completely different volcanic rocks dif- 
fering in the decline of the variation curves to coordinate axes or otherwise in the spzed of alkaline growth in the process of differentiation. One of these classes includes lavas of oceanic islands (lines 1-4, in fig. 1), the other embraces lavas of island arcs (lines 5-7) together with alkaline rocks of continental volcanoes (lines 8-10).

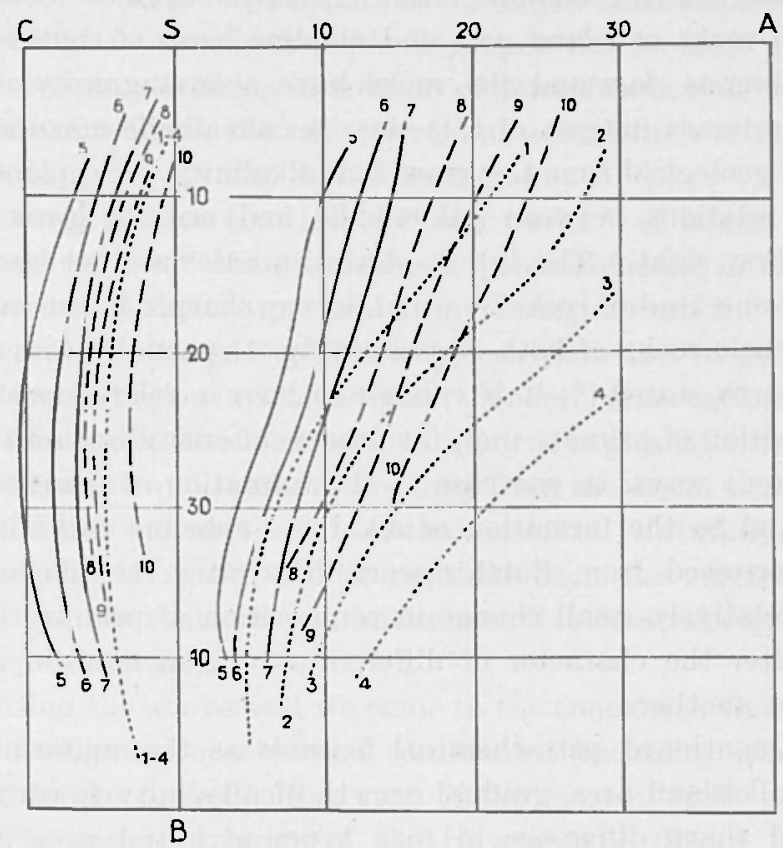

Fig. 1 - The diagram of the types of the natural associations of volcanic rocks (by. A. Zavaritsky).

The order numbers of lines given in fig. 1, are in conformity with certain petrochemical types of rocks: 1) volcanoes of the Hawaian archipelago; 2) the lavas of the Tahiti Islands; 3) and 4) very alkaline types of rocks, which occur in some islands of the Pacific, the Indian and the Atlantic; 5) "Pelee type" according to Burri, including lavas of Eastern Kamchatka, Japan volcanoes etc.; 6) "San Francisco type" according to Burri; 7) "Yellowstone Park type" according to Burri; 8) intermidiate type separating calc-alkaline rocks from pure alkaline (" Etna type " according to Zavaritsky); 9) " Rosita Hills type" to which lavas of alkaline province of Eastern Asia belong; 10) very alkaline continental lavas (Uyun Kholdong in NE China, Bufimbira in Africa and others). 
The transition from calc-alkali lavas of island arcs to the lavas of continental volcanoes takes place not only in space but also in time. In many places ( $\mathrm{NE}$ Asia, the Carpatians etc.) there are examples that old lavas which correspond to the geosyncline stage of development (or island arc stage) being calc-alkaline ones and more young lavas (of continental stage) being alkaline ones. Thus, the class of rocks embracing calc-alkali rocks of island arcs and alkaline lavas of continents belongs to a continuous class and the rocks have aconsanguinity.

The primary magma of this class is calc-alkalic magma and in the course of geological time the growth ni alkalinity takes place.

The relations between calc-alkalic and oceanic lavas are not so clear at first sight. The intermediate varieties are not known and the change of one kind of rocks by other is very sharp. At the same time the fields of basic rocks of both classes (in fig. 1) partially cover each other and as Barth stated (*) it is enough to have a relatively small change in composition of primary melt for process of cristallization to go absolutely different ways: in one case to the formation of quartz dacites and ryolites and to the formation of alkaline nepheline rocks in the other. Fig. 2 borrowed from Barth's work illustrates the above statement. Thus, a relatively small change in composition of primary magma may greatly alter the character of differentiation and transfer one type of rocks into another.

The mentioned petrochemical features as the uniformity of rock types in all island ares, gradual growth of alkalinity towards the continents and sharp difference in rock types of island arcs and oceanic islands are of general importance. That the lavas belong to one or the other type of rocks depends on oceanic, continental or intermediate (island arc) location or, otherwise, on the continental or oceanic type of the Earth's crust and does not depend at all on the composition and structure of upper layers of the crust (with a few exeptions). The uniformity of lavas of oceanic islands or island ares is well known. The continental volcanoes also issue lavas uniform enough (in the petrochemical sence) irrespective of the location of volcaneos in the regions of Mesozoic or Tertiary folding (the Carpatians), the rift zone (Africa) or on the old platform (NE China).

It had been long proposed on the basis of general theoretical postulates that the feeding sources of volcanoes are situated at great depths

(*) Вактн, Том. F. W., Theoretical Petrology, 1952. 
of some scores of kilometers. Recently the depth of magmatic heart of Kliuchevsky Volcano in Kamchatka was determined as being 50-70 km. The independence of petrochemistry of lavas from the geological structure and the structure of the upper layers of the crust proves once more the idea that the feeding sources of the volcanoes are situated out of limit of the crust - in the upper part of the Earth's mantle where there is no sharp change in chemistry depending upon the concrete geological structure. Moreover, a striking uniformity of petrochemistry of volcanism over vast territories shows the relative role of assimilation of crust material in the magma on its way to the surface.

A well known opinion that the "Pacific rocks" of island ares are only derivatives of the "Atlantic magma" contaminated in the upper layers of the crust by sialitic material being brought from the adjoining mainland to the dipping geosyncline is in contradiction to geophysical observations in the regions of island arcs. Modern observations proved that in some arcs the crust of the continental type is present only immediately beneath the arc and is absent not only from the ocean side but also in the mariginal seas - from the side of the continent. Naturally, in these conditions the supply of the sialitic material from the surface cannot take place. Thus, the source of contamination, if it does take place, may be only of depth character.

Summarizing the above said we come to the conclusion that the two main types of magmas: oceanic and continental (including island ares) are connected to the corresponding type of the crust in space as well as genetically. The oceanic magma of the Hawaii type (line 1 in fig. 1) is an ancestral magma for all the other magmas (primitive magma by Tilly, etc.). Under the conditions of gradual increase in alkalinity in the course of normal evolution this magma becomes more and more alkaline (shift from line 1 to line 4 in fig. 1). During contamination of this magma by sialitic material the oceanic magma turns into the calc-alkalic one (the transition from point " $\mathrm{N}$ " to point " $\mathrm{X}$ " in fig. 2 or from line 1 to line 5 in fig. 1). This sharp change of magmatic type is related to the upflow of sialitic material from depths of the Earth's mantle.

The island arcs indicate these narrow areas of the Globe where at present the processes of depth differentiation and the rise of the sialitic material from the depths of the mantle to its surface take place.

This process leads to the thickening of the crust and at the same time sharply changes the chemistry and the whole character of volcanism. Further more, with the termination of the flow of portions of substance from the depths of the mantle the normal process of magmatic evolution 
in the direction of increase of alkalinity is renewed and the magma gradually turns into the alkaline continental one.

On its way to the Earth surface through the crust magma in most cases does not undergo a notable contamination and does not change visibly the main features of its petrochemistry. The composition of primary magmas seems to correspond to basalts or more basic rocks. It is necessary to note that within the limits of the so called " andesine line" the basalts and andesite-basalts also have a wide occurence.

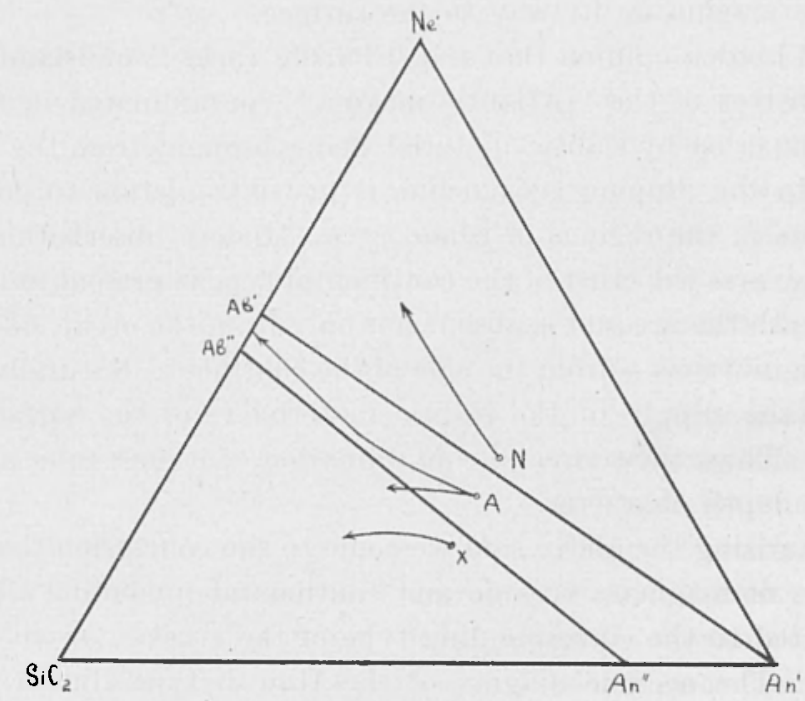

Fig. 2 - Different possible results of the fractional crystallization of basalt melts. (by T. Barth).

More acid varieties of rocks are the products of differentiation of the corresponding more basic magmas in a relatively small volumes of volcanic vents. A separate volcano or a group of neighbouring volcanoes may issue lavas different in their acidity but they all will belong to one narrow type and their figurative points will be situated along the same line in fig. 1. Somewhat noticeable shift across the curves (i.e. change in alkalinity) is not observed as a rule in short periods of time. Numerous cases of substitution of more acid lavas by more basic ones during the same eruption are known; then after the cease of activity which is long enough for differentiation, there may appear acid lavas followed by basic ones and so on. However a noticeable change in alkalinity (in petroche- 
mical sence) in this case is not observed as all lavas belong to one type. The change in alkalinity and substitution of one type of magma with another happens only in the course of geological periods of time.

Thus, the consideration of petrochemistry of lavas lead us to the conclusion that volcanism is not purely a surface or introcrustal process, but together with tectonic activity in general, represents the surface expression of the primary undercrustal processes that govern all the course of the Earth's development. The formation of island ares is one of the necessary and most essential links of this process.

\section{$S O M M A R Y$}

It was shown that there are two petrochemically sharply different classes of lavas: 1) alkali lavas of intraoceanic islands, and 2) calc-alkali lavas of island arcs together with alkali lavas of intracontinental volcanoes. The two main types of lavas: oceanic and continental (including islands arcs), are connected in space to the corresponding types of the Eearth's crust, but petrochemical peculiarities are independent of local geological features and structure of upper layers of the crust. Magmatic harts of volcanoes are located in the upper part of the mantle and petrochemical features reflect the changes in chemistry of subcrustal substance. Oceanic magma is an ancestral one and in the course of a normal evolution this magma becomes more and more alkaline. Calk-alkali magma of island arcs is derivative one and it is generated by the contamination of the oceanic magma with sialitic material upflowing from depths of the mantle (assimilation of crust material is insignificant). The island arcs indicate these narrow areas of the Globe where the process takes place. It leads to a thickening of the crust and changes sharply the petrochemistry and the whole character of volcanism. Then in the course of the normal evolution the calc-alkali magma turns gradually into continental alkali one. Thus, volcanism is not purely a surface or intracrustal process, but it represents the surface expression of primary subcrustal processes that govern all the course of the Earth's development. The formation of island arcs is one of the necessary and most important links of the process.

\section{RIASSUNTO}

Si e visto che ci sono due classi di lava lievemente diversa per la composizione petrochimica: 1) le lave "alkali" delle isole oceaniche e 2) le lave "calc-alkali" degli archi insulari insieme con le lave "alkali" dei vulcani 
continentali. I due principali tipi di lava: oceanica e continentale (compreso gli archi insulari), sono connesse nello spazio ai corrispondenti tipi di crosta terrestre, ma le peculiarita petrochimiche non dipendono dalla locale composizione geologica e dalla struttura degli strati piu elevati della crosta. Gli "harts" di magma dei vulcani si trovano nella parte più elevata del mantello e le composizioni petrochimiche riflettono $i$ mutamenti chimici della sostanza della sottocrosta. Il magma oceanico e ancestrale e nel corso di una evoluzione normale questo magma diventa sempre più alcalino. Il magma " calc-alkali" delle "island arcs" e un derivato ed e prodotto dalla contaminazione del magma oceanico con materiale sialitico che emerge dalle profondita del mantello (l'assimilazione del materiale della crosta e insignificante). Gli archi insulari indicano queste ristrette zone del globo dove il processo ha luogo. Questo processo porta ad un ispessimento della crosta $e$ muta lievemente la petrochimica e tutto il carattere del vulcanismo. Quindi nel corso della normale evoluzione il magma "calc-alkali" si cambia gradualmente in "alkali" continentale. Percio il vulcanismo non e semplicemente una superficie o un processo intercrostale, ma rappresenta l'espressione della superficie dei processi subcrostali primari che regolano tutto il corso dello sviluppo della Terra. La formazione degli archi insulari e uno degli aspetti necessari e più importanti del processo. 